\title{
3D-CG イメージで学ぶ肺外科のための局所解剖 一より良い区域切除を目指して一
}

\author{
荒井 他嘉司 \\ 国立病院機構災害医療センター名誉院長・結核予防会複十字病院顧問
}

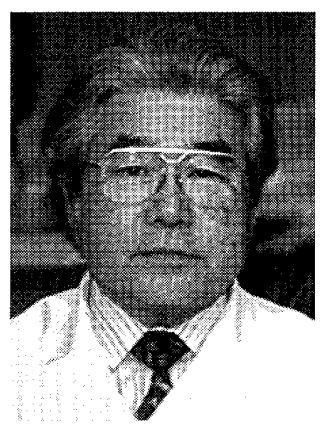

東北大学医学部卒業（1961年3月), 国立仙台病院にてインターン (1961年4月), 東北大学院博士課程（東北大学抗酸菌病研究所外 科学教室）(1962年4月), 同 修了. 東北大学院学位・医学博士を授与さる (1966年3月), 静岡県立富士見病院外科勤務（1966年4 月), 結核子防会結核研究所付属療羑所外科勤務（1966年8月), 国立療盖所中野病院呼吸器外科勤務 (1975年3月 1993年1月), 西 ドイッ・ベルリン市 Heckeshorn 病院（呼吸＼cjkstart器外科）留学（1976年11月～78年4月）, 国立国際医療センター病棟部長（1993年10 月), 国立国際医療センター副院長（1996年4月），国立病院機構 災害医療センター 院長（1996年10月），退官 国立病院機構 災害医療センター 名誉院長（2002年4月）

近年, 肺癌の診断の進歩に伴い, 肺区域切除術が再び見直されてきた。肺区域切除術は肺結核外科全盛時代に は標準術式として大きな比重をしめていた，その後外科対象疾患の中心が肺癌に移り肺葉切除術が標準的手術と なったため, 肺区域切除術は久しく忘れられていた，肺癌の早期発見および診断の進歩に伴い，小型肺癌に対寸 る手術が増え，かつ縮小手術の成績が見直されてきた。 それに伴い肺癌に㧍いても肺区域切除術の適応が見直さ れ, 呼吸器外科を目指す医師にとって正しい区域解剖の知識が求められる時代が再来した.

1945年頃より Boyden により詳細な肺区域解剖の研究成果が報告されるようになったのに伴い，1948年頃より 区域解剖に則った肺区域切除術の報告が Overholt を初めとして多数発表されるようになった.

我が国では結核予防会結核研究所において山下英秋, 塩沢正俊らにより1949年頃から肺の区域解剖ならびに区 域切除術の研究が進められ, その研究成果が1952年から1957年頃にかけて報告され, 肺区域切除術は肺結核に対 する標準的手術のひとつとしての地位を確立した，当時の呼吸器外科医はその研究成果を基に胸部エックス線断 層写真上での血管のトレースや肺模型の作成などをしながら区域解剖を勉強してきた.

近年, 3D-CT を用いてきれいな肺の立体像が得られる時代になった，区域解剖の勉強をするには，個々症例 の3D-CT 立体像を朋いるのも良い方法のひとつであろう。また, CT 画像のトレースから肺の構造を再構築する 方法もあり，これについては大貫恭正教授から追加発言の中で紹介してもらう予定である.

いずれの方法を用いて勉強するにせよ，区域解剖の基本的知識の会得が先決である．基本的な区域解剖の知識 を觔強する手段として, 現時点では既刊の教科書の平面図から, 自らの頭の中で肺解剖図を立体的に構築しなけ ればならない。

さて, IT 時代に相応しい勉強法はないかとの疑問に, 演者はパソコンのなかで観たい方向から自由に観察で きる立体的な肺モデルがあれば良いのではないかと考えた。

そこで，演者は2006年から2年間にわたり3D-CGソフトを用いて3次元の肺・気管支・血管モデルを自作して きた．3次元立体像の作成には Mac Pro, CGソフト Shade 9 Standard を用い, レンダリング, アニメーション 設定は800x600pixel，500コマ・360度回転を標準とした．肺・気管支・血管それぞれについて立体的な全体像の ほか，様々なバリエーションについて肺葉，区域ごとに立体像を作成し，パソコン上で像を観たい方向に自由に 回転しながら観察できる立体解剖図譜に仕上げた。講演では自ら作成した3D-CGイメージを用いて, 呼吸器外 科に必要な肺局所解剖の一般的な知識に加え, より良い肺区域切除術を目指して必要な知識を部位ごとに解説す る予定である。 